Гульчехра СИДИКОВА, оқытушы, Қазтұтынуодавы Қараванды университеті, 100009, Қазақсстан Республикасы, Қараванды қ., Академическая көш., 9 E-mail:siddik84@mail.ru

\title{
ҚАЗІРГІ КУНДЕГІ ШЕТЕЛ ТІЛДЕРІН ОҚЫТУ ҮРДІСІ
}

Мақала студенттерді шет тілін оқыту сабағында заманауи технологияларды, олардың дидактикалық әлеуетін қолдануға арналған. Мақалада жаңа технологияларды енгізуге ықпал ететін факторлар, цифрлық ұрпақтың психологиялық сипаттамалары атап өтілген.

Түйінді сөздер: ақпараттық технологиялар, инновациялар, қолдану.

Гульчехра СИДИКОВА, преподаватель, Карагандинский университет Казпотребсоюза, 100009, Республика Казахстан, г. Караганда, ул. Академическая, 9

E-mail:siddik84@mail.ru

\section{СОВРЕМЕННЫЕ ПОДХОДЫ В ОБУЧЕНИИ ИНОСТРАННЫМ ЯЗЫКАМ}

Статья посвящена использованию современных инновационных технологий при обучении студентов иностранным языкам. Авторы статьи рассматривает психологические и дидактические факторы, способствующие внедрению новых технологий в учебный процесс.

Ключевые слова: информационные технологии, инновация, использование.

Gulchehra SIDIKOVA, Teacher, Karaganda University of Kazpotrebsoyuz, 100009, Republic of Kazakhstan, Karaganda, Akademicheskayast., 9, E-mail: siddik84@mail.ru

\section{MODERN TRENDS OF TEACHING FOREIGN LANGUAGES}

The article is devoted using modern innovative technologies in teaching foreign languages to students. The authors of the article consider psychological and didactic factors that contribute to the introduction of new technologies in the educational process.

Key words: information technology, innovation, use.

Қазіргі уақытта шетел тілін оқытудың коммуникативтігі, интерактивтілігі, аутенттілігі тілді үйрену үрдісінің мәдени контексте болуы үстемдікке ие болуда.

Шетел тілін оқыту технологиясының тиімділігінің көрсеткіштері мыналар:

- Студенттердің моральдық психологиялық ,интелектуалдық және жас ерекшеліктерін ескеру.

- Окуға жағымды көңіл күй қалыптастыру.

- Ұстаз бен студент арасында сөз алмасу, ғылыми қарым-қатынас және әріптестік принципін орнықтыру.

- Студенттердің еске сақтау қабілеті мен творчестволық деңгейін көтеру арқылы белсенділігін арттыру.

- Оқуды игеруге мультимедиялық және басқа да техникалық арсеналды кең іске қосу.

- Сабақтардың бітуімен студенттердің келешекке қанағаттануының қорытынды нәтижесі.

- Білім беру технологиясының үш түрлі типі бар. Олар: дәстүрлік, инновациялық және ақпараттық.

Окушылардың заманауи цифрлық ұрпағы үшін дәстүрлі және ақпараттық білім берудің артықшылықтарын үйлесімді қолданатын технологияларды жасау қажет. Бұл проблема шетел тілін оқытуға толығымен қатысты, оның процесі жаңа ақпараттық қоғамда қажет болатын шетел тілінің коммуникативтік құзыреттілігін және шет тілінің ақпараттық құзыреттілігін арттыруға бағытталуы керек.

Қазіргі кезде цифрлық технологиялар адам қызметінің әр түрлі салаларына көбірек енуде. Білім беру саласы да ерекшелік емес, атап айтқанда студенттерге шет тілдерін үйрету. Бұл дайындықтың сапасы көбінесе жаңа буын технологияларын, яғни ақпараттық-коммуникациялық технологияларды енгізуге және олардың мүмкіндіктерін оқу процесінде пайдалануға байланысты.

Студенттер жеткілікті жоғары дәрежеге ие цифрлық технологиялардың заманауи әлемінде дәстүрлі және ақпараттық білім берудің артықшылықтарын үйлесімді түрде үйлестіретін, 
оқушылардың оқуға деген ынтасын арттыратын және шет тілін меңгеру деңгейін көтеретін, осындай оқыту әдістерін әзірлеу қажет.

Ақпараттық технологиялардың қарыштап дамыған дәуірінде қоғам болашақ мамандарға білімді өз бетінше игеру үшін қажетті біліктер мен дағдыларды қажет етеді, және оларды тәжірибеде әртүрлі мәселелерді тиімді шешу, фактілерді жинау және талдау, жалпылау мен дәлелді тұжырымдар жасау үшін қолдану қажет [2]., бастап. 257; 6, б. 46], жетістікке жету үшін коммуникативті, әртүрлі жағдайларда бірлесіп жұмыс жасау, жанжалды жағдайлардан шығу жолын іздеу қажет; заманауи ақпараттық технологияларды қолдану арқылы туындайтын мәселелерді шешу жолдарын іздеп, сыни және шығармашылық тұрғыдан ойлау; өзіндік мәдени деңгейін көтеру үшін өз бетінше жұмыс жасау. Окушылардың білім беру процесінде жоғарыда аталған дағдылары мен танымдық дағдыларының дамуы белсенді оқыту технологияларының арқасында жүзеге асады [4, б. 267].

Қазіргі уақытта оқыту құралын таңдау кезіндегі негізгі көрсеткіш - бұл Еуропа Кеңесі жасаған және тиімді жалпыеуропалық ақпарат алмасу жүйесін ұсынатын шет тілдерін меңгерудің соңғы деңгейлеріне жету болып табылады [3, б. 90].

Тілді игеру көңілді, мазмұнды сабақ және нақты тілдік шығармашылық болуы керек. Тек осы жағдайда ғана оқушы білім алушыдан үйренушіге айналады, дербестікке ие болады және жаңа білім беру стандарттарына сәйкес өзін-өзі дамытуға ұмтылады»[1, б. 21-22].

Қазіргі кезде ғаламдық компьютерлендіру адам қызметінің барлық салаларын, соның ішінде ғылым мен білімді қамтып отыр. Интернеттің дамуы және оку процесін жеңілдететін көптеген компьютерлік бағдарламалардың пайда болуы шетел тілдерін окуды едәуір өзгертті, түпнұсқа көздермен жұмыс істеуді тез және жеңілдетті.

Білім беру үдерісінде заманауи технологияларды қолдану мәселесі күн санап көбеюде. Бұл жаңа техникалық құралдар ғана емес, сонымен қатар оқытудың жаңа формалары мен әдістері, оқудағы жаңа тәсіл. Шетел тілін үйренуде заманауи технологияларды қолдана отырып, біз алдымызға қойған басты мақсат - студенттерге шетел тілін оқыту сапасын арттыру, олардың коммуникативті мәдениетін қалыптастыру және дамыту, практикалық тұрғыдан оқыту үшін технологияны қалай тиімді пайдалануға болатындығын көрсету.

Ағылшын тілін оқытуда заманауи технологияларды қолдану арқылы оқу дағдыларын жетілдіруге көмектесетін әртүрлі тәсілдер мен әдістер талқылануда. Осы әдістердің қатарына ағылшын тілін үйренуге арналған веб-сайттар, компьютерлік тілдерді оқыту бағдарламалары, презентацияға арналған бағдарламалық жасақтама, электронды сөздіктер, чат және электрондық пошта арқылы хабарлама жіберу бағдарламалары, CD-ойнатқыштарды тыңдау және видеоклиптерді үйрену жатады.

Оку үрдісінде технологияны қолданғаны үшін ағылшын тілі кабинетінің типтік студенттерінің жауаптарын бағалау үшін кейс-стади жасалды. Осы практикалық зерттеу барысында қағаз ағылшын тілінің қолданыстағы әдеттегі оқу құралдарының кемшіліктері мен шектеулеріне диагноз қойып, белгілі бір ұсыныстар мен ұсыныстармен қорытынды жасайды.

Ақпараттық-коммуникациялық технологияны (АКТ) білімге енгізу оқытудың жаңа парадигмаларын тудырады. Біз технологияның әлемдік әлемінде өмір сүріп жатырмыз және технологиядағы жетістік педагогикалық ұсыныстарға негізделеді. Сондықтан тілді пайдаланушылардың шектеулерін заманауи технологияларды қолдану арқылы қалай жақсарту керектігін қайта қарау қажет болуы мүмкін. Жаңа технологиялар мен педагогикалық ұсыныстардың өзара әрекеттесуі екінші тілді үйренушілердің гетерогенді қажеттіліктерін қанағаттандыру деңгейінде анықталды және оқушылардың шектеулерін барынша азайтуға бағытталған кез-келген жаһандық жаңалық болып табылады, бұл тез өзгеретін технологиялар әлемінде қолайлы жағдай.

Бұл жұмыс қазіргі заманғы технологиялардың тілді оқытушыларға да, студенттерге де көмектесе алатындығына шолу болып табылады. Технологиялық дамыған елдер бастан кешірген АКТ-ның қарқынды өсуі оларға оқыту мен оқудағы кейбір кедергілерді жеңуге көмектесті. Оқыту мен оқудағы заманауи технологияларды қолдану мұғалімдерге, студенттерге және басқаларға өздерінің қоршаған ортасынан тыс адамдар қауымдастығына қосыла алады, сыни тұрғыдан қарастыруға, талдауға, үлес қосуға, сынға алуға және ұйымдастыруға мүмкіндік береді. бүкіл қоғамның өзгеруіне байланысты. Қазір жаңа технологиялар, мысалы, жаңа бағдарламалық жасақтама мен желілік қосымшалармен жабдықталған компьютерлік жақсартулар, тәрбиешілерге шектеулер мен академиялық қайшылықты мәселелерді ескере отырып, кеңістік пен уақытты бағындыруды едәуір жеңілдетеді. Енді біз оқудың қалаулы нәтижелеріне жету үшін кез-келген уақытта әлемдегі кез-келген жерге окуды жеткізе аламыз. 
Бұрын оқу мен білім дегеніміз тек бетпе-бет дәрістер оқуды, кітаптарды немесе баспа материалдарын оқуды, конспектілеуді және тапсырмаларды көбіне сұрақтарға жауап беру немесе эссе жазу түрінде орындауды білдіретін. Қысқаша айтқанда; білім беру, оқыту және оқыту мұғалімсіз, кітаптарсыз және тақталарсыз мүмкін емес деп саналды. Бүгінгі таңда білім беру мен оқыту мүлдем жаңа мәнге ие болды. Компьютерлер әр сыныптың маңызды бөлігі болып табылады, ал мұғалімдер оқушыларға заттардың қалай жұмыс істейтінін және жұмыс істейтінін көрсету үшін DVD, CD-ROM және видео қолданады. Оқушылар тақырыптық материалдармен интерактивті құралдар мен CD-ROM дискілерді пайдалану арқылы өзара әрекеттесе алады. Сонымен қатар, әр окушы өз қарқынымен алға баса алады [1].

Технология оқыту шығындарын төмендетуге және өнімділікті арттыруға көмектеседі: көптеген оқушыларға қысқа мерзімде жету үшін технологияны пайдаланудың тағы бір артықшылығы - оқу шығындарын төмендету. Корпоративті және академиялық оқу орындары оқушыларға бір оқушыға сабақ беру шығындарын азайта алады. Сонымен қатар, технология сандық нәтижелерді береді және оқушыларға бұл ақпаратты тез және жақсы нәтижелермен қолдануға мүмкіндік береді. Технологияны қолдану арқылы оқушылар уақытты үнемдеп, олардың өнімділігін арттыра алады. Бұл екі тармақ те жетілдірілген технологиялық құралдардың жоғары шығындарын ақтайды.

Технологияны оқытуда оқудағы тосқауылдар: әрине, білім беру технологиясы оқушыларға жағымды әсер етуі үшін, ол жақсы дайындалып, дайындалуы керек. Ақпаратты тарату үшін қолданылатын құралдар оқушыларды ескере отырып жасалуы керек. Компьютерлік / технологиялық сауаттылықтың жетіспеушілігі сияқты факторлар да қарастырылуы керек. Мектептер мен кәсіпорындар білім беру технологиясы қарапайым құрал екенін және оның жетістігі көбіне оны жоспарлаудың көлеміне байланысты екенін есте ұстауы керек. Осы факторлардың барлығын ескерген кезде білім беру технологиясын пайдалану дұрыс таңдау бола алады.

Технологияның дамуы мен цифрлық революцияның өрлеу кезеңінде шетел тілі мұғалімдері мультимедиялық технологиялар қолдайтын шет тілін оқыту мен оқудың жақсы ортасын құрудың тиімді жаңа тәсілдері туралы ойлануды қажет етеді. Нәтижесінде шет тілдерін оқыту саласында компьютерлік тілді оқыту танымал бола бастады. Компьютерлік тілді оқыту мүмкіндіктерін талдау негізінде бұл жұмыс мультимедияның EFL сыныптарында маңызды рөл атқара алатындығына бағытталған. Әдеби шолу мультимедияны дамыту және анықтамалар бойынша жүргізілді. Сонымен қатар, әдебиеттерге шолу теориялық және педагогикалық тұрғыдан оқыту әдісі ретінде мультимедияда жүргізілді. компьютерлік тілді оқыту артық, кемшіліктерін талдай отырып, кәсіби оқытушылар мен білікті мұғалімдер ұсынған оқытудың кейбір практикалық және тиімді жолдары сабақта мультимедияны тиімді пайдалану туралы талқылануда[2].

Компьютерлік оқыту бағдарламалары дәстүрлі оқыту әдістеріне қарағанда бірқатар артықшылықтарға ие, бұл бірінші кезекте тікелей аудиовизуалды интерактивті өзара әрекеттесу құралдары. Оларды сабақта дәстүрлі оқыту әдістерімен бірге қолдану сөйлеу әрекетінің әр түрлі түрлерін жаттықтыруға, лингвистикалық құбылыстардың табиғатын түсінуге, лингвистикалық қабілеттерді қалыптастыруға, коммуникативті жағдайлар туғызуға, тілдік және сөйлеу дағдыларын автоматтандыруға мүмкіндік береді және оқушының өзіндік жұмысының индивидуалды тәсілі мен қарқындылығын жүзеге асыруды қамтамасыз етеді, сонымен қатар оқушылардың танымдық белсенділігі, ынтасы мен білім сапасының артуына ықпал етеді.

Цифрлық технологияларды таңдаудағы басты қиындық, ең алдымен: «Оқыту процесінде нені қолдану керек?» деген сұрақ қойып және осы қосымшалардың барлығын ескере отырып, біз таңдалған ресурстарды қолдану кезінде және оларды қалай дұрыс қолдану керектігі туралы хабардар болмағандықтан, тікелей пайдалану кезінде туындайтын қиындықтар туралы жиі біле бермейміз. Мұғалімнің таңдалған ресурстарды пайдаланудың барлық мүмкіндіктері мен ережелерін алдын-ала зерттеуге уақыты немесе қалауы жеткіліксіз болуы мүмкін.

Біздің қосымшаларымыз бен бағдарламаларымызды тиімді пайдалану үшін алдымен сұрақтар қоюымыз керек: «Неге? Компьютерлік технологияларды оқу процесінде қолданудың негізгі мақсаты неде?»

Себептер әр түрлі болуы мүмкін:

- зерттелген туралы түсінікті жақсарту;

- оқушыларды қолдануға ынталандыру арқылы оқу уақытын арттыру сыныптан тыс уақытта білім беру қосымшалары мен ресурстарды ұсыну;

- мұғалімнің жұмыс тиімділігінің деңгейін арттыру; - оқушылардың дербестігін дамыту;

- компьютерлік технологиялармен жұмыс істеу дағдыларын арттыру нологиялар; 
- студенттерде шешімділік және сияқты қасиеттерді дамыту нәтижеге жетудегі мақсаттылық;

- оқушыларды болашақ өмірге дайындау;

- оқушылардың ынтасын арттыру;

- пайдаланылатын физикалық ресурстардың санын азайту және т.б.

Шет тілдерін оқытуда интернет-ресурстарды пайдалану қазіргі заманғы шындыққа, студенттердің құзыреттілігіне барлық қажетті және сәйкес келетін жағдайларды жасауға мүмкіндік береді.

Мұғалім цифрлық технологияларды таңдаған кездегі негізгі сұрақтар: нені пайдалану керек, қалай пайдалану керек және ең бастысы, осы немесе басқа ресурстарды не үшін пайдаланады. Бұл ең алдымен сабақтың негізгі мақсаттары мен міндеттерін, демек, осы сабақ аясында компьютерлік инновацияларды қолдануды анықтау қажет. Осыдан кейін біз осы мақсаттар мен міндеттерге неғұрлым тиімді жету үшін қандай ресурстарды пайдалану керек екенін және сайып келгенде таңдалған оқыту құралы қалай жұмыс істейтінін сұрап алуымыз керек. Жоғарыда аталған мәселелерді егжей-тегжейлі түсіну студенттердің оқу үдерісіне қатысуын және олардың болашақ кәсіби іс-әрекеттерін ойдағыдай жүзеге асыруға қажетті дағдылары мен қабілеттерін дамытуды едәуір арттыра алады.

\section{Әдебиеттер тізімі:}

1. Беляева И.С. Из опыта составления учебного пособия по английско- му языку для студентов технического вуза / И.С.Беляева, А.Е.Шабанова // Вестник Тверского государственного технического университета. Серия: Науки об обществе и гуманитарные науки. - 2016. - o 3. - С. $18-23$.

2. Голубева Н.Б. Развитие критического мышления как важный эле- мент формирования профессионально-ориентированной иноязычной ком- петенции // Вестник университета. - 2015. No 3. - C. 257-261.

3. Иванова Т.А. Обучение иностранным языкам в тверском государ- ственном техническом университете в условиях интеграции России в еди- ное образовательное пространство / Т.А. Иванова, И.В. Скугарева, А.Е. Ша- банова // Вестник Тверского государственного технического университета. Серия: Науки об обществе и гуманитарные науки. - 2016. - № 2. - С. 88-93.

4. Окань Г.И. Активные методы обучения в вузе: содержание и особен- ности внедрения // Научный диалог. 2012. № 1. С. 265-270.

5. Рябцева Н.К. Новые коммуникативные тенденции в современной культуре и инновации в области преподавания иностранного языка // Лингвистика и методика преподавания иностранных языков : периодиче- ский сборник статей. Выпуск 8. Электронное научное издание. - М.: Институт языкознания РАН. - 2016. - 557 с.

6. Трапезникова Г. А., Хабибуллина Ф. Я. Использование технологии критического мышления при обучении студентов языкового факультета об- щественно-политической лексике // Вестник Марийского государственно- го университета. - 2017. - Т. 11. - No 2 (26). -С. 46-52.

7. Akai O.M., Kalashnikova A.A., Kalashnikov I.A., Pshenichnaya A.Yu. Pragmatic level of language personality in social networks. Current issues of linguistics and didactics : The interdisciplinary approach in humanities (CILDIAH 2017) Proceedings of the 7th International Scientific and Practical Conference. Advances in Social Science, Education and Humanities Research. - 2017. - P. 9-14.

8. Бим И.Л., Биболетова М.3. Возможные формы и содержание курсов обучения иностранным языкам в начальной школе. // Иностранные языки в школе. №2. с. 3.

9. Jonassen, H. Constructing learning environments on the web: Engaging pupils in meaningful learning. EdTech 99: EducationalTechnology Conference and Exhibition 1999: Thinking Schools, Learning Nation. - 1999 - p. 45-46.

\section{References:}

1. Beliaeva I.S. Iz opyta sostavleniia uchebnogo posobiia po angliisko- mu iazyku dlia studentov tekhnicheskogo vuza / I.S.Beliaeva, A.E.Shabanova // Vestnik Tverskogo gosudarstvennogo tekhnicheskogo universiteta. Seriia: Nauki ob obshchestve i gumanitarnye nauki. - 2016. - No 3. - S. 18 23.

2. Golubeva N.B. Razvitie kriticheskogo myshleniia kak vazhnyi ele- ment formirovaniia professionalno-orientirovannoi inoiazychnoi kom- petentsii // Vestnik universiteta. - 2015. - No 3. - S. $257-261$. 
3. Ivanova T.A. Obuchenie inostrannym iazykam $v$ tverskom gosudar- stvennom tekhnicheskom universitete $\mathrm{v}$ usloviiakh integratsii Rossii $\mathrm{v}$ edi- noe obrazovatelnoe prostranstvo / T.A. Ivanova, I.V. Skugareva, A.E. Sha- banova // Vestnik Tverskogo gosudarstvennogo tekhnicheskogo universiteta. Seriia: Nauki ob obshchestve i gumanitarnye nauki. - 2016. - No 2. - S. 88-93.

4. Okan G.I. Aktivnye metody obucheniia v vuze: soderzhanie i osoben- nosti vnedreniia // Nauchnyi dialog. 2012. No 1. S. 265-270.

5. Riabtseva N.K. Novye kommunikativnye tendentsii v sovremennoi kulture i innovatsii v oblasti prepodavaniia inostrannogo iazyka // Lingvistika i metodika prepodavaniia inostrannykh iazykov : periodiche- skii sbornik statei. Vypusk 8. Elektronnoe nauchnoe izdanie. - M.: Insti- tut iazykoznaniia RAN. $-2016 .-557 \mathrm{~s}$.

6. Trapeznikova G. A., Khabibullina F. Ia. Ispolzovanie tekhnologii kriticheskogo myshleniia pri obuchenii studentov iazykovogo fakulteta ob- shchestvenno-politicheskoi leksike // Vestnik Mariiskogo gosudarstvenno- go universiteta. - 2017. - T. 11. - No 2 (26). -S. 46-52.

7. Akai O.M., Kalashnikova A.A., Kalashnikov I.A., Pshenichnaya A.Yu. Pragmatic level of language personality in social networks. Current issues of linguistics and didactics: The interdisciplinary approach in humanities (CILDIAH 2017) Proceedings of the 7th International Scientific and Practical Conference. Advances in Social Science, Education and Humanities Research. - 2017. - R. 9-14.

8. Bim I.L., Biboletova M.3. Vozmozhnye formy i soderzhanie kursov obucheniia inostrannym iazykam v nachalnoi shkole. // Inostrannye iazyki v shkole. №2. s. 3.

9. Jonassen, H. Constructing learning environments on the web: Engaging pupils in meaningful learning. EdTech 99: EducationalTechnology Conference and Exhibition 1999: Thinking Schools, Learning Nation. - 1999 - p. 45-46. 